\title{
Paget's disease in a painting by Quinten Metsys (Massys)
}

J Dequeker

It is now nearly 120 years since Wilks ${ }^{1}$ described the condition that Sir James Paget called "osteitis deformans." Although Paget considered that he was describing a new disease, the fact that he was able to collect data on 23 cases during his lifetime suggests that it was an established condition. On 13 December 1882 in the Bradshaw lecture "On some rare and new diseases" at the Royal College of Surgeons of England, Paget stated that he could not find any specimens of old bones in the London museums or described in any catalogue that resembled those in osteitis deformans. Since then, however, several ancient and prehistoric specimens have been reported to show the effects of Paget's disease: a parietal bone found in an ancient Egyptian tomb, ${ }^{3}$ remains of a skull dating from the Gallo-Roman period, ${ }^{4}$ and a femur dating from the neolithic period. ${ }^{5}$ The peculiar shape of some

BrMed J 1989;299:1579-81

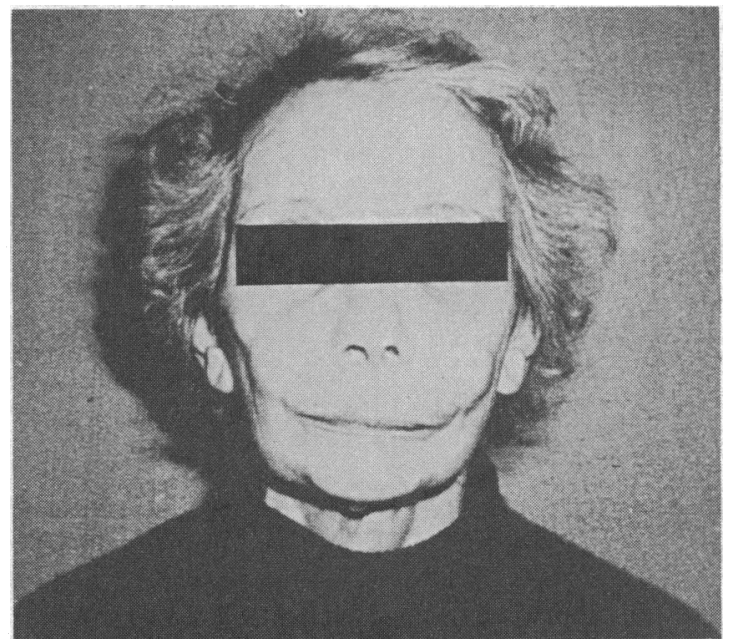

FIG 2-Woman with Paget's disease affecting maxillary bones

Neanderthal skulls has been attributed to pagetoid lesions, and the Piltdown skull may have been affected by the same disorder. ${ }^{6}$ Naiken in $1971^{7}$ and Baker in $1973^{8}$ suggested that Beethoven was affected by Paget's disease, which may have been responsible for his deafness. Whether osteitis deformans was a fairly new disease in London at the end of the nineteenth century is neither fully refuted nor confirmed.

Works of art of many different kinds may provide an important source of evidence of ancient disease. A search for arthritis in old paintings has yielded several examples of rheumatoid lesions, giving paleopathological arguments that rheumatoid arthritis, though for the first time clearly described by Landré Beauvais in 1800 , is not a modern disease. ${ }^{910}$ I have studied possible pagetoid lesions of the skull and clavicles in a painting A Grotesque Old Woman (fig 1) attributed to Quinten Metsys (1465-1530), who was born in Leuven and who had his studio in Antwerp.

\section{The ugly duchess}

The painting represents an old woman holding a rosebud. She is dressed in a costume with a large décolletage and a head dress of Italian fashion. The realism of each detail and the caricature-like face are most striking. The face is ugly, painfully accurate, neatly and smoothly executed with deformations, disfigurement, and distortions. The nostrils, for example, are odd, somehow more open, more flaring, and excessively arched. The broadness of the cheeks is accentuated by the ears, which stand out sharply from the head, and there is a bulging of the area beneath the nose. This broad and high cheeked face, with a wide coarse nose, gives the whole face an open, snorting look that has something of the wild animal about it - the lion. This typical face has been called by clinicians facies leontina, as seen infrequently in patients with Paget's disease and those with leprosy.

Figure 2 shows a woman with Paget's disease in which the maxillary bones are affected. In the painting the deformity of the face can be explained by hypertrophy of the maxillary bones, which gives this prominent upper lip and pushes up the nose and the
FIG 1-A grotesque old woman. After Quinten Metsys (?) (1465/6-1530). Reproduced by courtesy of the trustees, The National Gallery, London 


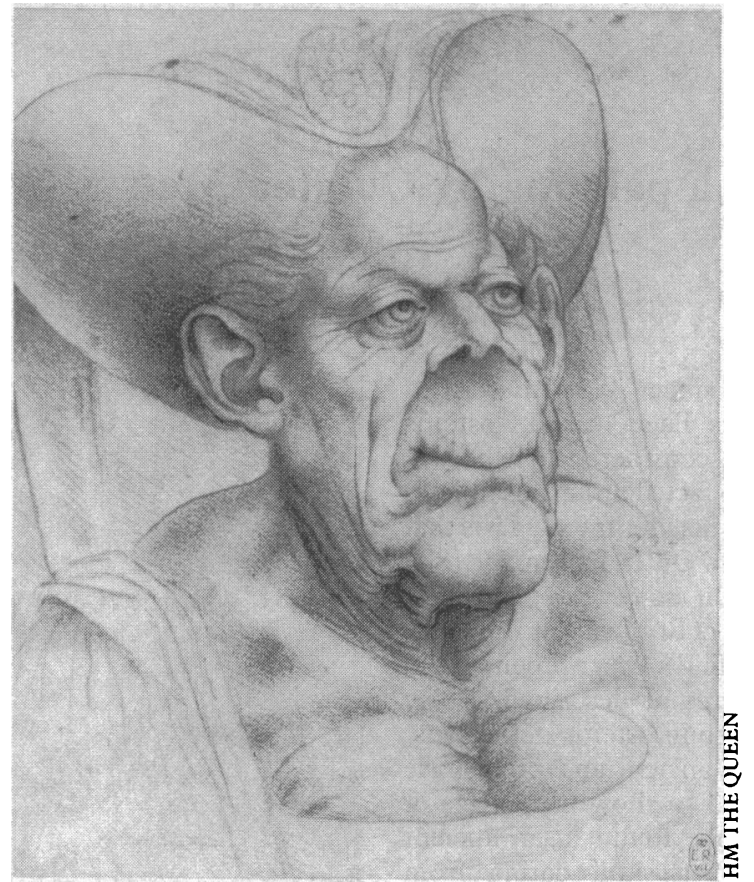

FIG 3-Drawing of old woman by Leonardo da Vinci

nostrils. The chin is probably also hypertrophied because otherwise a retrognathism would be the consequence of the maxillary hypertrophy. A cellular mole on the right cheek is clearly seen. The right clavicle is bowing and hypertrophied distally. The hypertrophy of the maxillary bones, mandibula, and clavicles is characteristic of pagetoid changes in bones.

\section{Portrait or caricature}

Although a work of art may provide evidence of ancient disease, the interpretation may be extremely difficult. Errors of diagnosis are commonly made either by seeing disease where none exists or by interpreting at face value a pathological appearance that is only the expression of an artistic convention.

Alistair Smith, commenting on this painting, declared that "it seems scarcely possible that the picture is a portrait that is made from life." that at the time it was painted, late in Metsys's career, there was an extensive interest in caricature and satire, which in the visual arts was especially prevalent in the north of Europe. It was mainly expressed in woodcuts that commented on contemporary events, and it is therefore unusual to find it in the medium of paintings, whose traditionally formal status generally excluded such subject matter. The fact that the woman holds a rosebud, with its association of fragile youth and awakening love, which is in contrast with the appearance of the sitter, points to the possibility that the painter made the image of "an old coquette" for the purpose of amusement or satire. This does not necessarily mean, however, that the painter invented his sitter; he could as well have used a model for this purpose. A facies leontina is such a grotesque deformity that the painter could not have forgotten once he had seen it.

A drawing by Leonardo da Vinci was probably the direct source for the painting. ${ }^{12}$ The drawing, a replica of which is held at Windsor Castle (fig 3), was copied almost exactly by Metsys, who added only details such as the lace and pattern of the head dress, the bodice, and most notably the hands with the rosebud and the ballustrade to accentuate the caricature of the old coquette. What is important here, however, is that Metsys had access to the drawing (or its replica), which he copied carefully. This was not Metsys's first dependence on a Leonardo drawing for his grotesque heads. On two separate occasions he borrowed from Leonardo's most renowned study, the five grotesque heads, in his Martyrdom of St fohn the Evangelist (1508-11), in a triptych (Koninklijk Museum, Antwerp) and in his Ill Matched Pair (National Gallery of Art, Washington). ${ }^{11}$ The grotesque figures of Leonardo's drawings (fig 4) resemble odd and grotesque personalities as seen in the margins of society and therefore are most likely portraits made from life. Several characteristic pathological features can be seen in these faces: in the upper and lower rowrhinophyma, macroglossia, facies leontina, hawk's nose, elongated skull, and macrognathia. The heads of the middle row resemble old fashioned Florentine respectability and caesarean personalities.

The old (possibly Italian) woman seen in Leonardo's drawing and copied in Metsys's painting may have had Paget's disease. Metsys probably painted this grotesque old woman to caricature the Florentine traders' community in Antwerp as representatives of usury and avarice. Because of its grotesque and caricature-like features this picture has survived for long in engravings, as seen for example in the engraving of Wenzel Hollar (1607-77) called Rex et Regina de Tunis (fig 5). That painters in those days did not disguise deformities of their patrons is shown by Metsys's portraits of Aegidius (1517) (Royal Museum of Arts, Antwerp), who is shown with a malformation of the thumb-namely, syndactyly - and of Erasmus (1517) (Galleria Nazionale d'Arte Antica, Palazzo Barberini, Rome), who has a $\mathrm{Z}$ deformity of the thumb. ${ }^{10}$

The jaws and facial bones are rarely affected by Paget's disease, and most cases seem to present at a young age. ${ }^{13}$ Clear facial deformity with undue prominence of both cheeks and leontiasis ossea results from advanced effects on the maxillary bones. The enlarged maxillae and hard palate may interfere with speech, mastication, and swallowing. As the lesion progresses gradually, however, patients and their relatives are often unaware of the disfigurement.

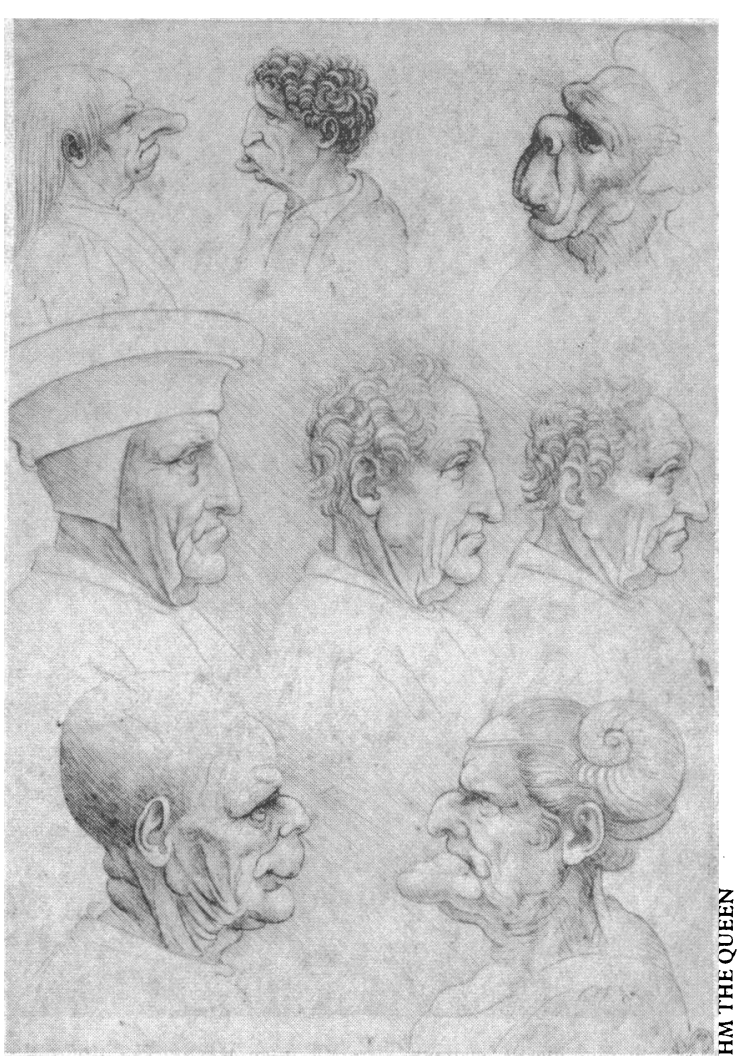

FIG 4-Drawing of grotesque heads by Leonardo da Vinci 


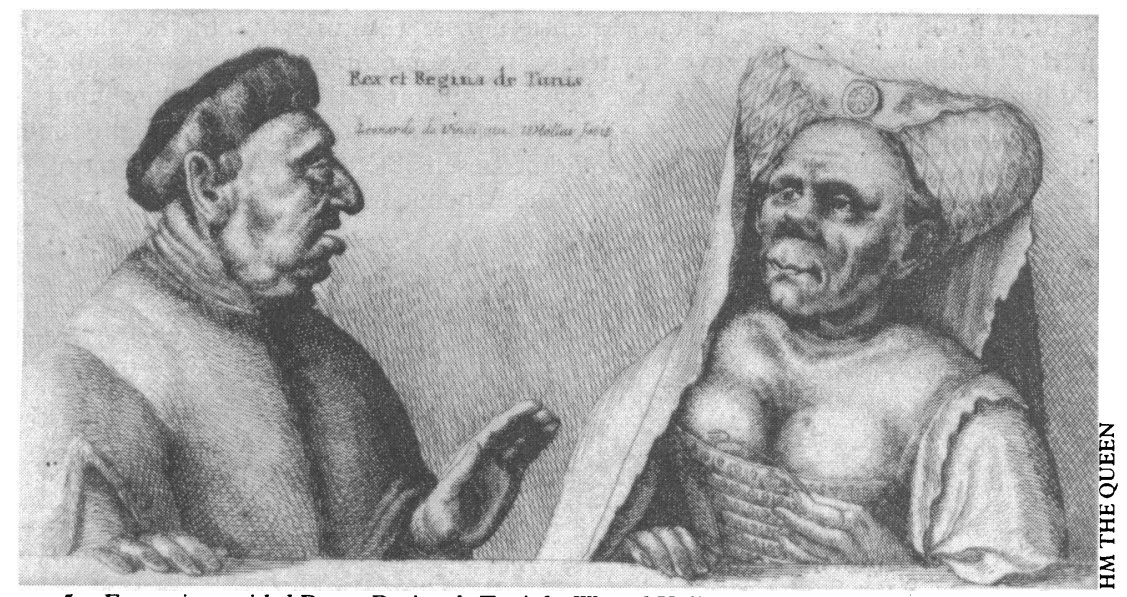

FIG 5-Engraving entitled Rex et Regina de Tunis by Wenzel Hollar

Patients with Paget's disease affecting the maxilla or mandible are often first detected by dentists as tooth extraction may cause problems and because any artificial dentures will not remain satisfactory for more than a few months.

The finding of pagetoid deformity, facies leontina, and hypertrophic clavicles in Metsys's painting questions the belief of Sir James Paget that Paget's disease was a condition that had arisen fairly recently.

I thank Professor M Smeyers, art historian, KU Leuven, for his critical advice and Dr V Parsons for providing figure 2.

1 Wilks S. Case of osteoporosis or spongy hypertrophy of bones. Transactions of the Pathological Society of London 1869;20:273-7.

2 Paget J. On a form of chronic inflammation of bones. Medico-chirurgical Transactions 1877;60:37-63.

3 Hutchinson J. On osteitis deformans. Illustrated Medical News 1889;2:169-79. 4 Astre G. Maladie osseuse pagetoide d'un crane gallo-romain? Revue de Pathologie Générale et Comparée 1957;57:955-61.

5 Pales L. Maladie de Paget préhistorique. Anthropologie 1929;39:263-70.

6 Moodie RL. Paleopathology. An introduction to the study of ancient evidence of disease. Urbans, Illinois: University of Illinois Press, 1923:348-448.

Naiken VS. Did Beethoven have Paget's disease of bone? Ann Intern Med 1971;74:995-9.

8 Baker D. The deafness of Beethoven. History of Medicine 1973;5:10-3.

Dequeker J. Arthritis in Flemish paintings (1400-1700). Br Med $\mathcal{J}$ 1977;i: 1203-5.

10 Dequeker J. Rheumatic diseases in visual arts: generat review. In: Appelboom T, ed. Art, history and antiquity of rheumatic diseases. Brussels: Elsevier, 1987:31-7.

11 Smith A. Early Netherlandish and German paintings. The national gallery schools of painting. London: Collins, 1985.

2 Silver L. Power and Pelf: a new-found old man by Massys. Simiolus 1977;9:63-92.

13 Hamdy RC. Paget's disease of bone: assessment and management. Eastbourne: Armour Pharmaceutical, 1981.

\section{Robbie's Fox cards}

\section{Sir James Howie}

Every year, between October and Christmas, Robbie (Sir Theodore) Fox, who was editor of the Lancet from 1944 to 1964, set about creating with his own hand his unique cards - Fox cards, he called them. These were sent at Christmas to personal friends and were certainly effective not only at giving pleasure to their recipients but at conveying something of Robbie's whimsical, humorous, and perceptive outlook on people and life. For example, he says: "I hope that any lack of gravitas in this card won't obscure my particularly good wishes." Indeed, on the contrary, the cards revealed his insistence on making his communications personal, relevant, and amusing. The cards are treasured by those who received them, and it is right that they should be shown to a wider audience.

One card says:

From bottom of psychologist's barrel - These lassies and laddies aren't goodies or baddies Instead (by my troth)

We're all of us both

[I know, I know. But even Shakespeare sometimes used outdated phrases].

Another tells us:

Thought for some other Day

"All beauty is relative but not all relatives are beautiful."

These are just a few examples that appeal to me; all of them are worth studying even if their reduced size requires the use of a hand lens.

\section{Portrait from memory}

But what of the man as I remember him? Can I do him as a portrait from memory?

I came to know him in May 1943, when the Lancet called him back from military service and he had to give up editing the Army Medical Department Bulletin, a publication that brought the War Office more approval than was usual for most of its published communications to serving medical officers. After Robbie's successor had to give up editing this unusual venture rather quickly and suddenly because of ill health, the pathology department sought Fox's advice about a successor. Fox went through the manuscripts awaiting publication in his successor's cupboard and found some that I had done at the request of the then editor, who had confessed that he needed help from anyone around who could write a little. I was then at Millbank Army Hospital hoping for orders to return to Nigeria, where I had spent two happy and profitable years in what was clearly a microbiologist's paradise. The head of the War Office decided to keep me in London for a time to get the malaria out of my system.

Fox recognised from reading my offerings that I had also written a few things for the L ancet and advised that I should be given a chance to edit the AMD Bulletin; this owed its surprising and unexpected success to his talent not only for choosing subjects of interest but for getting the various War Office consultants to provide some of the necessary information and eventually to accept his edited version of what he had been offered and had himself unearthed from various sources. He did this really well and was most anxious to see the bulletin continue. So he persuaded the War Office to appoint me to the pathology department, where I edited the bulletin as part of my duties as a deputy assistant director of pathology. Fox assured me that the duties were far from simple but that from his office at the Lancet he would give me whatever practical help and advice I thought necessary. He kept his word faithfully. I could count on an almost weekly visit from him and could call him at any time if I needed help and advice, which I certainly did. We became friends - it was one of the best friendships of my life.

\section{How did you learn to write?}

Fox asked me how I had learnt to write one evening after I had written an annotation for him which he said he needed for the Lancet as soon as possible. I called on him with the handwritten script two hours after he had asked me to do it. "What on earth!" he exclaimed.
Edinburgh EH13 0BU professor of bacteriology

BrMed f 1989;299:1581-4 